Vol 13, Issue 10, 2020

\title{
ANTIMICROBIAL STUDIES OF DIFFERENT EXTRACTS OF HOLOPTELEA INTEGRIFOLIA (ROXB.) LEAVES
}

\section{REKHA TRIPATHI* \\ Department of Applied Sciences, Maharaja Surajmal Institute of Technology, New Delhi, India. Email: rekhatripathi@msit.in} Received: 15 July 2020, Revised and Accepted: 18 August 2020

ABSTRACT

Objective: The aim of this study was to examine various extracts of leaves of Holoptelea integrifolia against some test bacteria and test fungi.

Methods: Disk diffusion method was adopted for the assessment of antimicrobial activity. Amikacin and nystatin were used as standard drugs for antibacterial and antifungal activity, respectively.

Results: The screening data indicated that all four extracts showed antibacterial activity against Staphylococcus aureus, but the growth of this bacteria was inhibited the most by the aqueous extract. In the case of antifungal efficacy, all the extracts inhibited the growth of almost all the test fungi. Petroleum ether and benzene extracts showed maximum efficacy against Aspergillus flavus, whereas methanolic extract and aqueous extract inhibited the growth of Rhizoctonia bataticola significantly.

Conclusion: Different extracts of leaves of $H$. integrifolia were significantly active against selected test fungi and they can be a harmless alternative of expensive conventional medicines.

Keywords: Holoptelea integrifolia, Leaves, Extracts, Antimicrobial efficacy.

(C) 2020 The Authors. Published by Innovare Academic Sciences Pvt Ltd. This is an open access article under the CC BY license (http://creativecommons. org/licenses/by/4. 0/) DOI: http://dx.doi.org/10.22159/ajpcr.2020.v13i10.39057

\section{INTRODUCTION}

Medically important plants are the best gift of nature to human beings to make their life healthier. The medicinal importance of plant(s) attracted the attention of chemists to study natural products. Plant products are being increasingly tried upon and utilized for various purposes in the field of pharmaceuticals. It is believed that the extracts and products of plants being natural are harmless to human beings and their environment.

In ancient times, the crude plant extracts had been used for the treatment of human infectious diseases [1-3]. Later on, chemists isolated the active principles and established their structures, including tannins, terpenoids, alkaloids, and flavonoids which have antimicrobial properties $[4,5]$. Therefore, the present work was undertaken with the antibacterial and antifungal studies of different extracts (petroleum ether, benzene, methanol, and water extract) of leaves of Holoptelea integrifolia (Roxb.) Planch. This plant belongs to the family Ulmaceae and common name is "Chilbil." $H$. integrifolia is a large spreading glabrous, deciduous roadside tree distributed throughout the country up to an altitude of $600 \mathrm{~m}^{3}$. Only a few plants of the family Ulmaceae are known, which have medicinal importance [6,7].

Fruits of Celtis australis (syn. C. caucasian) are used in amenorrhoea and colic, Coltricia cinnamomea, Commiphora wightii, and Citrus reticulata (syn. Gironniera reticulata) are used as a blood purifier in itch and other cutaneous eruptions [6]. A review of literature revealed that $H$. integrifolia is also medicinally important, the juice of boiled mucilaginous bark is applied to rheumatic swellings, the stem fibers tied to the upper arm are useful for the patients suffering from malarial fever [6-9], and the ethanolic extract of the bark also showed significant inhibition of breast cancer formation [10]. The crude leaf sap of $H$. integrifolia was found to be mildly active against bean common mosaic virus [11], it is also useful in colic pain, intestinal worms, filaria, piles, pox, vitiligo, in wound healing $[12,13]$, and petroleum ether extract and methanolic extract of leaf delayed onset of convulsion and also prolonged the onset of tonic convulsion in mice [14]. Keeping the medicinal importance in view, the antibacterial and antifungal investigation of different extracts of leaves of H. integrifolia was undertaken.

\section{METHODS}

Plant materials

The leaves of $H$. integrifolia (Roxb.) Planch. were collected from the Campus of Rajasthan University, Jaipur, and identified from the Botany Department of Rajasthan University, Jaipur (Herbarium sheet No. RUBL 4334). The shade dried and powdered leaves were stored in an airtight container.

\section{Extraction}

Powdered leaves of $\mathrm{H}$. integrifolia were extracted for $24 \mathrm{~h}$ on a steam bath with pet.ether, benzene, methanol, and water separately. Later, each of these extracts was filtered and re-extraction $(2 \times)$ of each residue was done for complete exhaustion. The extracts were collected, concentrated in vacuum, and stored in a dark-colored bottle at $4{ }^{\circ} \mathrm{C}$ separately.

\section{Sources of test organisms}

Test bacteria

In vitro antibacterial activity was evaluated against most common pathogenic bacteria such as Escherichia coli, Klebsiella aerogenes, Proteus vulgaris, and Pseudomonas aeruginosa as Gram -ve and Staphylococcus aureus as Gram +ve. All the test organisms were obtained from SMS Medical College, Jaipur and were maintained on Nutrient Broth Medium.

\section{Test fungi}

The pure cultures of test fungi, namely Aspergillus flavus, Aspergillus niger, Fusarium moniliforme, and Rhizoctonia bataticola were obtained from the Seed Pathology Laboratory, Department of Botany, University of Rajasthan, Jaipur and were maintained on Potato Dextrose Agar (PDA) medium. 
Table 1: Antibacterial activity



IZ: Zone of inhibition (in $\mathrm{mm}$ ) including the diameter of disk $(6 \mathrm{~mm})$, AI: Activity index=(inhibition zone of sample/inhibition zone of standard),

Standard: Amikacin $=10 \mu \mathrm{g} / \mathrm{ml}$. ( \pm ) Trace activity: (-) No activity. E. coli: Escherichia coli, K. aerogenes: Klebsiella aerogenes, P. vulgaris: Proteus vulgaris, S. aureus:

Staphylococcus aureus

Table 2: Antifungal activity

\begin{tabular}{|c|c|c|c|c|c|c|c|c|c|}
\hline \multirow[t]{3}{*}{ Extract } & \multirow[t]{3}{*}{ Dose $\mu \mathrm{g} / \mathrm{disk}$} & \multicolumn{8}{|c|}{ Test fungi } \\
\hline & & \multicolumn{2}{|c|}{ A. flavus } & \multicolumn{2}{|c|}{ A. niger } & \multicolumn{2}{|c|}{ F. moniliforme } & \multicolumn{2}{|c|}{ R. bataticola } \\
\hline & & $\mathbf{I Z}^{*}$ & AI* & IZ & AI & IZ & AI & IZ & AI \\
\hline \multirow[t]{2}{*}{ Pet.Ether } & 1000 & 16 & 0.83 & 18 & 0.75 & 12 & 0.42 & 11 & 0.39 \\
\hline & 500 & 14 & 0.72 & 15 & 0.62 & \pm & - & \pm & - \\
\hline \multirow[t]{2}{*}{ Benzene } & 1000 & 15 & 0.78 & 14 & 0.58 & 17 & 0.60 & 14 & 0.50 \\
\hline & 500 & 12 & 0.62 & 11 & 0.46 & 12 & 0.42 & \pm & - \\
\hline \multirow[t]{2}{*}{$\mathrm{MeOH}$} & 1000 & 14 & 0.73 & 12 & 0.50 & 21 & 0.75 & 20 & 0.76 \\
\hline & 500 & 12 & 0.63 & 10 & 0.41 & 13 & 0.46 & 18 & 0.69 \\
\hline \multirow{2}{*}{ Aqueous extract } & 1000 & 14 & 0.72 & 10 & 0.41 & 18 & 0.64 & 20 & 0.76 \\
\hline & 500 & 10 & 0.52 & 8 & 0.33 & 15 & 0.54 & 16 & 0.57 \\
\hline
\end{tabular}

IZ: Zone of inhibition (in $\mathrm{mm}$ ) including the diameter of disk (6 mm), AI: Activity index=(inhibition zone of sample/inhibition zone of standard),

Standard: Nystatin=100 units/disk. ( \pm ) Trace activity: (-) No activity. A. flavus: Aspergillus flavus, A. niger: Aspergillus niger, F. moniliforme: Fusarium moniliforme,

R. bataticola: Rhizoctonia bataticola

\section{Culture of test microbes}

For the bacteria cultivation, the nutrient agar plates were seeded with the suspension of the bactericidal strain and incubated at $37^{\circ} \mathrm{C}$ for $24 \mathrm{~h}$.

However, for the cultivation of fungi, the test fungi were incubated at $37^{\circ} \mathrm{C}$ for $48 \mathrm{~h}$ and the cultures were maintained on PDA medium by regular sub-culturing.

Test plates for both bacteria and fungi were prepared by pouring $10-15 \mathrm{ml}$ of the respective medium in the Petri-dishes and used for screening. For antibacterial activity, a fresh saline suspension of the test bacteria was prepared from a freshly grown agar slant, while for antifungal activity, the test fungi were spread using a sterile swab.

\section{Bactericidal and fungicidal assay}

Disk diffusion method $[15,16]$ was adopted for bactericidal and fungicidal efficacy because of re-productivity and precision. The different test organisms were preceded separately over previously sterilized culture medium plates using a sterile swab. Sterilized filter paper disks of $6 \mathrm{~mm}$ diameter (Whatman no.1) containing $500 \mu \mathrm{g}$ and $1000 \mu \mathrm{g}$ dose of test compounds were placed on the agar surface along with disks impregnated with standard drugs (Amikacin for bacteria and Nystatin for fungi)in the concentration of $10 \mu \mathrm{g} / \mathrm{ml}$ and 100 units/disk respectively.

Before incubation, these plates were placed at $4^{\circ} \mathrm{C}$ for $1 \mathrm{~h}$ for the maximum diffusion of the test compound from the test disks into media and thereafter were incubated at $37 \pm 2^{\circ} \mathrm{C}$ for $24 \mathrm{~h}$ for bacteria and for $48 \mathrm{~h}$ for fungi, then the diameters of inhibition growth zones could be easily observed. The experiment was performed 3 times to minimize the error and the mean values were referred.

\section{RESULTS AND DISCUSSION}

\section{Bactericidal activity}

In the case of bactericidal activity against E. coli, K. aerogenes, $P$. vulgaris, P. aeruginosa, and $S$. aureus, all four extracts (pet.ether, benzene, methanol, and aqueous) inhibited the growth of S. aureus. The aqueous extract exhibited marked activity against $S$. aureus (activity index $[\mathrm{AI}]=0.78,1000 \mu \mathrm{g} /$ disk and $0.52,500 \mu \mathrm{g} /$ disk). Methanolic and aqueous extracts also exhibited moderate activity against $P$. vulgaris (Table 1).

\section{Fungicidal activity}

In the case of antifungal activity against A. flavus, A. niger, F. moniliforme, and $R$. bataticola, all four extracts demonstrated inhibition against all the test fungi. The pet.ether extracts exhibited marked activity against A. flavus (AI=0.83, $1000 \mu \mathrm{g} /$ disk and 0.72, $500 \mu \mathrm{g} /$ disk $)$ and significant activity against $A$. niger $(\mathrm{AI}=0.75,1000 \mu \mathrm{g} / \mathrm{disk}$ and $0.62,500 \mu \mathrm{g} /$ disk). The benzene extract was also effective at both concentrations (AI=0.78, $1000 \mu \mathrm{g} /$ disk; $\mathrm{AI}=0.62,500 \mu \mathrm{g} /$ disk) against A. flavus and showed average activity against $F$. moniliforme (AI=0.60, $1000 \mu \mathrm{g} /$ disk; $\mathrm{AI}=0.42,500 \mu \mathrm{g} /$ disk). The methanolic extract of leaves of $H$. integrifolia demonstrated maximum activity against $R$. bataticola (AI $=0.76,1000 \mu \mathrm{g} /$ disk and 0.69, $500 \mu \mathrm{g} /$ disk) and significant activity (AI $=0.75,1000 \mu \mathrm{g} /$ disk) against $F$. moniliforme. Likewise, the aqueous extract was found to have maximum activity against $R$. bataticola $(\mathrm{AI}=0.76,1000 \mu \mathrm{g} /$ disk; $\mathrm{AI}=0.57,500 \mu \mathrm{g} /$ disk (Table 2).

The study of the literature clearly indicates the medicinal importance of crude extracts of different plant parts of $H$. integrifolia. The leaf extracts exhibited antiviral activity [11], wound healing activity [13], anticonvulsant activity [14], and this research work also indicates the pronounced activity against some test fungi. Further research on the isolation of active principles can be very useful for the mankind.

\section{CONCLUSION}

As per the experimental data above, it can be successfully concluded that different extracts of leaves of $\mathrm{H}$. integrifolia displayed remarkable activity against all the test fungi. Thus, the leaves may be a source of effective and novel antifungal drugs. 


\section{AUTHOR'S CONTRIBUTIONS}

The author declares that this entire work was done by the author named in this article.

\section{CONFLICTS OF INTEREST}

The author declares no conflicts of interest.

\section{FUNDING}

I have received no funding.

\section{REFERENCES}

1. Alviano DS, Alviano CS. Plant extracts: Search for new alternatives to treat microbial diseases. Curr Pharm Biotechnol 2009;10:106-21.

2. Malini M, Abirami G, Hemalatha V, Annadurai G. Antimicrobial activity of ethanolic and aqueous extracts of medicinal plants against waste water pathogens. Int J Res Pure Appl Microbiol 2013;3:40-2.

3. Zhang R, Eggleston K, Rotimi V, Zeckhauser RJ. Antibiotic resistance as a global threat: Evidence from China, Kuwait and the United States. Global Health 2006;2:6.

4. Dorman HJ, Deans SG. Antimicrobial agents from plants: Antibacterial activity of plant volatile oils. J Appl Microbiol 2000;88:308-16.

5. Talib WH, Mahasneh AM. Antimicrobial, cytotoxicity and phytochemical screening of Jordanian plants used in traditional medicine. Mol 2010;15:1811-24.

6. Chopra RN, Nayar SL, Chopra IC. Glossary of Indian Medicinal Plants. New Delhi: CSIR; 1971.

7. Kirtikar KR, Basu BD. Indian Medicinal Plants. Vol. 3. Allahabad: Lalit Mohan Basu and Co.; 1975. p. 2292.

8. ICMR. Medicinal Plant of India. Vol. 2. New Delhi: ICMR; 1987. p. 48.

9. Hemadri K, Raj PV, Rao SB, Sharma CR. Folklore claims from Andhra Pradesh. J Sci Res Plant Med 1980;1:37-49.

10. Soujanya J, Silambujanaki P, Krishna VL. Anticancer efficacy of Holoptelea integrifolia, planch. Against 7, 12-dimethyl benz(a) anthracene induced breast carcinoma in experimental rats. Int J Pharm Pharm Sci 2011;3:103-6.

11. Tripathi RN, Tripathi RK, Pandey DK. Assay of antiviral activity in the crude leaf sap of some plants. Environ India 1981;4:86-7.

12. Sharma PV. Classical Uses of Medicinal Plants. Varanasi: Chaukhambha Orientalia; 1996.

13. Chandrasekar D, Madhusudhana K, Ramakrishna S, Diwan PV. Evaluation of antimicrobial, antioxidant and wound-healing potentials of Holoptelea integrifolia. J Ethnopharmacol 2008;115:249-56.

14. Sutar RC, Kasture SB, Kalaichelvan VK. Evaluation of anticonvulsant activity of leaf extract of Holoptelea integrifolia (Roxb) planch in experimental animals. Int J Pharm Pharm Sci 2014;6:308-11.

15. Gould JC, Bowie JH. The determination of bacterial sensitivity to antibiotics. Edinb Med J 1952;59:178-99.

16. Andrews JM. BSAC standardized disc susceptibility testing method. J Antimicrob Chemother 2001;4:43-57. 